\title{
Prudence, Principle and Minimal Heuristics: British Public Opinion Toward the Use of Military Force in Afghanistan and Libya
}

\author{
Jason Reifler, Harold D. Clarke, Thomas J. Scotto, \\ David Sanders, Marianne C. Stewart and Paul Whiteley
}

\section{Research Highlights and Abstract}

This article shows:

- Clear pluralities of British survey respondents opposed their nation's military interventions in Afghanistan and Libya.

- Opposition to involvement in the conflicts mostly a function of the costs the missions would impose on the nation and concerns about the morality of the missions.

- Attitudes towards the parties and their leaders are weak predictors of the respondents' attitudes towards involving the nation's military in the conflict.

- Survey experiment reveals the positions leaders and parties took on sending additional British troops into Afghanistan did not prime support or opposition to such a 'surge'.

Scholarship is divided on the primary drivers of public support for the use of military force. This article addresses this controversy by comparing three competing models of British public opinion towards the use of military force in Afghanistan and Libya. Analyses of national survey data demonstrate that cost-benefit calculations and normative considerations have sizable effects, but leader images and other heuristics have very limited explanatory power. These results are buttressed by experimental evidence showing that leader cues have negligible impacts on attitudes towards participation in a military 'surge' in Afghanistan. The minimal role heuristics played in motivating citizen support and opposition to the conflicts in these two countries contrast with their significant relationship to citizen attitudes towards the British intervention in Iraq. These conflicting results suggest that the strength of leader and partisan cues may be animated by the intensity of inter-elite conflict over British involvement in military interventions.

Keywords: public opinion; foreign policy attitudes, British politics

Over the past decade, the protracted wars in Iraq and Afghanistan have caused thousands of casualties and cost trillions of dollars. Students of international relations and public opinion have reacted by making sustained efforts to delineate the factors governing citizens' decisions regarding whether to support or oppose such conflicts. Significant strides have been made, but understanding is still incomplete 
due in no small part to data limitations of various kinds. Studies that examine attitudes towards war over time (e.g. Mueller 1973; Gartner and Segura 1998) have relied on aggregate data, thereby blunting the ability to explain individuallevel variations in such attitudes. Studies that do examine war support at the individual level (e.g. Liberman 2006) often rely on datasets created primarily for other purposes and the range of theoretically interesting explanatory variables is limited. ${ }^{1}$ Although the growth in experimental research in political science has helped to identify factors that shape attitudes towards war (e.g. Herrmann et al. 1999; Berinsky 2007; Gartner 2008; Gelpi et al. 2009), statistical power concerns typically prevent the use of factorial designs that incorporate multiple relevant dimensions in a single study. Yet another hurdle to developing a broad understanding of public attitudes towards war is that, to date, most of the relevant opinion data has been gathered in a single country-the United States. These several data limitations mean that there are few studies that permit direct comparisons of the ability of theoretically motivated rival models to make general claims. In consequence, forces shaping public opinion in a vital policy area remain imperfectly understood.

The present article attempts to inform understanding of war support/opposition by bringing competing theoretical concerns together in a series of rival models designed to explain variations in public opinion about British involvement in two important recent military conflicts. Specifically, we examine British opinion about the war in Afghanistan as well as opinion about providing military support for rebels attempting to overthrow Libyan dictator, Muammar Qaddafi. Explanatory models of interest focus on cost-benefit considerations, morality concerns and several possible decision-making heuristics. Multivariate analyses of data gathered in the Continuous Monitoring Survey (CMS) component of the 2010 British Election Study (BES) demonstrate that cost-benefit calculations and normative concerns have strong effects on attitudes towards military involvement, but party leader images and other heuristics have much less explanatory power. Additional supporting evidence for the minor effects of leader cues is provided by a national survey experiment examining support for a British contribution to the 'surge' in forces in Afghanistan. The conclusion reprises major findings and discusses implications for understanding factors influencing public opinion about Britain's involvement in wars and other militarized international disputes.

Data for the Afghanistan analyses were gathered in a large, representative national survey $(N=21,195)$ of the British electorate conducted in February 2009. This survey was commissioned as part of the ongoing Continuous Monitoring Survey (CMS) component of the 2010 British Election Study (BES). Two monthly CMS surveys, fielded in March and April of $2011(N=2145)$ were used to measure British public opinion toward the military intervention in Libya. ${ }^{2}$ The surveys included questions measuring approval or disapproval of the British missions in Afghanistan and Libya, as well as questions tapping judgments about the morality, costs and benefits of Britain's participation in the conflict, and beliefs about whether the mission would end in success. Other questions focused on a variety of potentially relevant political opinions, attitudes and beliefs such as party leader images, party identification and risk acceptance-aversion as well as media consumption patterns and socio-demographic characteristics. 


\section{Three Theoretical Perspectives on Public Opinion and War}

In this article, we seek to combine three explanations for war support that are both complementary and competing: (1) cost-benefit calculations (or prudence), (2) moral-reasoning (or principle), and (3) elite cues plus demographic factors (heuristics). These theoretical approaches are complementary in the sense that each is likely to contribute to explaining war support, but they are competing because research to date strongly contests which is the most important factor. To shed light on the question of the relative importance of these factors, we combine the three approaches in a single empirical analysis by adapting a model specification familiar to students of political behavior-Riker and Ordeshook's (1968) $P^{*} B-C+D$ model of the calculus of voting turnout. We discuss each of the three approaches in turn to explicate their theoretical motivations and how we incorporate them into a unified empirical framework.

\section{Prudence}

A prominent strand in recent research on public opinion formation focuses on rational decision-making encompassing a broad range of political issues, including decisions about war and related aspects of foreign policy. Proponents of this approach assert that citizens perform cost-benefit calculations when making up their minds about the desirability of using force to settle international disputes (e.g. Jentleson 1992; Page and Shapiro 1992; Larson 1996; Herrmann et al. 1999; Gelpi et al. 2005/2006, 2007 and 2009; Gartner 2008). Although points of emphasis and particulars vary, these studies (all conducted in the United States) share a common framework-citizens think rationally about why their country is going to war while also taking into account what costs are to be paid. ${ }^{3}$ When it comes to decisions about the use of military force, the public is 'pretty prudent' (Jentleson 1992).

One potential criticism of the existing 'reasoning citizen' studies of public opinion about war is that although theoretically the models are about costs and benefits, empirically there has been a heavy focus on costs (e.g.; Mueller 1973; Gartner and Segura 1998; Gelpi et al. 2005/2006, 2007 and 2009). There has much less emphasis on benefits, perhaps because that is a more difficult concept to measure (and possibly impossible to measure with aggregate data). ${ }^{4}$ As elaborated below, we address this concern by directly asking about the level of benefits survey respondents expect from the nation's involvement in the conflicts in Afghanistan and Libya.

A second critique of the 'reasoning citizen' line of foreign policy attitude research is more fundamental-following Converse's (1964) classic study and numerous ensuing works on mass belief systems (see Delli Carpini and Keeter 1997), the claim is that most citizens are not capable of making the kinds of cost-benefit calculations that rational actor models require. It is further argued that people rely on readily available cues-what Gigerenzer (2008) calls 'fast and frugal heuristics' - to make high stakes political judgments in contexts of substantial uncertainty (see also Kahneman et al. 1982; Gigerenzer et al. 2011; Kahneman 2011). For example, Berinsky (2007; see also Berinsky and Druckman 2007) argues that the process by which citizens make judgments about war is one where people 'follow the 
leaders' - adopting positions based on perceptions of the positions taken by political elites. However, it is important to note that the elite cues literature is far from monolithic, a topic which we consider in greater detail when we discuss heuristics below.

To incorporate the cost-benefits component in our more general explanatory model, we employ an expected utility specification. The model has three predictor variables: $\mathrm{B}$ for benefits, $\mathrm{C}$ for costs and $\mathrm{P}$, a probability of success term (which discounts $\mathrm{B}$ ). With theoretically motivated variables for the $\mathrm{P}, \mathrm{B}$, and $\mathrm{C}$ terms, this specification allows us to integrate key features of several existing models of attitudes towards war-including perceptions of success (e.g. Feaver and Gelpi 2004; Gelpi et al. 2009), benefits (e.g. Jentleson 1992; Jentleson and Britton 1998), and costs (Mueller 1973; Gartner and Segura 1998; Karol and Miguel 2007; Kriner and Shen 2007). We consider both collective (societal) and personal costs. The same basic formulation has been used extensively in analyses of voting turnout (e.g. Blais 2000; Clarke et al. 2009a and 2009b). While originally proposed to explain electoral participation (Riker and Ordeshook 1968), we believe that it is generalizable to other political phenomena.

Perhaps the largest difference between applying the model to political participation and attitudes towards war is the meaning of the P term. While the probability of a single voter being decisive in an election is generally extremely small (Gelman et al. 1998), it is in some measurable way possible. The same is not true for war support; it is difficult to think of a mechanism by which an ordinary citizen's actions could be decisive. This observation does not lead us to dismiss the discounting of B by $\mathrm{P}$, but rather suggests interpreting $\mathrm{P}$ in a way consistent with the war support literature. Given the hypothesized importance of perceptions of success in understanding opinions about war (Eichenberg 2003; Gelpi et al. 2005/2006 and 2009; Gartner 2008), we interpret the P term as a subjective judgment of the likelihood of success of a conflict. Accordingly, our empirical measure for the P term is an 11-point (0-10) scale tapping beliefs concerning the likelihood of the war being successful. ${ }^{5}$

It also is important to consider the meaning of the $\mathrm{B}$ and $\mathrm{C}$ variables in the model. As discussed above, benefits may be the most difficult measurement task for a public opinion cost-benefits model. Citizens may view many different benefits as coming from a war. To account for this variation in perceptions of benefits, we use a general measure to tap the concept of collective benefits of successful prosecution of the conflict. Specifically, the B variable is a five-category Likert-scale based on a question asking respondents whether they agree or disagree with the statement that 'Britain will benefit in the long run from participating in the war in Afghanistan'. ${ }^{6}$

Regarding costs, the primary way of measuring them in existing research on public opinion and war has been to use statistics on military casualties. However, most of these studies rely either on aggregate-level time series data or individual-level experimental data rather than cross-sectional survey data such as we employ here. (Assuming that the data of interest are gathered within the relatively short time horizons encompassed by typical public opinion surveys, costs measured in casualties will essentially be constant.) Another problem is that when calculating the expected utility of war, someone could be concerned about the personal (egocen- 
tric) costs that might be incurred or the collective (sociotropic) costs that one's country might experience. Here, we measure these two types of costs separately with responses to five-category agree-disagree questions. Perceived personal costs are ascertained by asking survey respondents whether they think Britain's involvement in the Afghanistan conflict 'threatens the safety of [their] family and [themselves]' and collective costs are assessed by asking whether the war in Afghanistan will 'seriously damage British interests around the world'.

In sum, the cost-benefit model of approval of the war in Afghanistan is:

$$
\begin{aligned}
(\text { Dis }) \text { Approval }= & f\left(\beta_{0}+\beta_{1}(\text { Success } * \text { Collective Benefits })-\beta_{2}\right. \text { CollectiveCosts } \\
& \left.-\beta_{3} \text { PersonalCosts }\right)
\end{aligned}
$$

In this model the dependent variable is measured by answers to a question asking respondents if they approve or disapprove of Britain's involvement in the war against the Taliban in Afghanistan, ${ }^{7}$ and the $\beta^{\prime}$ s are parameters to be estimated. Covariates, i.e. the benefits and costs variables, are treated such that strong agreement is coded ' 5 ' and strong disagreement is coded 1 '.

\section{Principle}

Just as the cost-benefit model is motivated by the conjecture that prudential considerations guide how people think about participation in international military conflicts, the morality model emphasizes the importance of moral principles. The model's claim is straightforward: moral considerations not only should, but actually do, inform public opinion about the desirability of engaging in wars. There is a strong tradition in political philosophy of the importance of morality in attitudes towards war. The morality model's origins are rooted in writings about international relations that extend back over several centuries, finding expression in the ideas of philosophers such as Aquinas and Kant. In the 20th century these ideas informed the design and implementation of international collective security mechanisms espoused by liberal-minded politicians acting in the Wilsonian idealist tradition (see, e.g. Holsti 1996/2004).

These political thinkers and politicians prefer to see countries resolve their differences with others through peaceful negotiations conducted in the framework of international organizations established for this purpose, but they do not rule out the possibility that a resort to war will occasionally be necessary and morally justified. For example, thirteenth-century philosopher St. Thomas Aquinas laid out guidelines for a 'just war theory' which provides criteria for deciding whether militarized inter-state conflicts are legitimate. In Aquinas' view, a war is only defensible if a country suffers injustices inflicted by an opponent. Modern extensions of the theory state that the war should be fought with appropriate force, within internationally agreed-upon conventions, and non-combatants and civilians should not be harmed (Mosley 2009).

Much more recently than Aquinas, there is also considerable empirical support that moral reasoning affects attitudes towards war. In particular, Liberman $(2006,2007)$ and Stein (2011) find that desires for punishment and retribution are strong predictors of these attitudes. When target states violate international norms, then 
some people support war because they believe the transgressors should be punished for what they have done. While support for the death penalty is often used as a proxy for this type of moral reasoning, we employ a more general measure because a desire for punishment is not the only form of moral reasoning that could affect war support. The central point is that citizens are capable of making normative judgments about highly publicized military conflicts such as the war in Afghanistan.

The morality model used to test the conjecture that such normative concerns influence public (dis)approval of the Afghanistan War is:

$$
\text { (Dis) Approval }=\mathrm{f}\left(\beta_{0}+\beta_{1} \text { Morality }\right)
$$

The dependent variable again is the five-point scale measuring approval/ disapproval of the war, and the $\beta$ 's are parameters to be estimated. The morality variable is based on responses to the statement: 'There is a strong moral case for Britain participating in the war in Afghanistan'. These responses are scored on a 1 to 5 scale, ranging from 1 ('strongly disagree') to 5 ('strongly agree').

\section{Heuristics}

As discussed above, research in political psychology and experimental economics indicates that many citizens use readily available cues to help them make decisions in situations in which the stakes are high and reliable information is in short supply. In the realm of public opinion about important government policies, political parties and their leaders often serve as key cue-givers, and citizens are prone to rely on them when asked to consider topics remote from their daily experiences. Existing literature suggests an important mechanism by which these cues operate involves citizens' affect toward parties and leaders. In their work on the 'likeability' heuristic, Sniderman et al. (1993) argued that people use feelings about parties and leaders to infer the positions of those groups and individuals on salient issues. In addition, research on 'hot cognition' by Lodge and Taber (2000) and others (e.g. Redlawsk 2002) indicates that people use their feelings about parties and leaders to evaluate the (de)merits of the issue positions they advocate. Taken together, these studies suggest that affect prompts an endogenous flow of inference and assessment. The larger claim is that such affective heuristics have powerful effects on public political psychology. Reviewing studies on the impact of affective heuristics, Kuklinski and Quirk (2000, 161) conclude that: '[i]n the constant interaction and cognition, emotion generally dominates'.

In terms of recent scholarship, Berinsky (2007; 2009, ch. 6) is perhaps most associated with a more 'pessimistic view' of understanding cue-giving, maintaining that elite cues tend to exert influence via in-group/out-group dividing lineswhether it is partisanship (as in the contemporary US politics) or nationality/ ethnicity (which was a factor in shaping World War II opinion). Boettcher and Cobb (2006) argue that citizens' opinions about war can be sensitive to even minor framing effects (though also see Boettcher and Cobb 2009). Similarly, Johnson and Tierney (2006) contend that public perceptions of war-related events can be substantially divorced from what is actually occurring on the ground, a disconnect 
caused by political elites and media sources. However, these findings may not be antithetical to a cost-benefit approach-they show that support is sensitive to the information available.

It is worth pointing out that not all models that rely on cue-taking reject a cost-benefit approach. Larson (1996) develops a cue-taking model of war support that explicitly posits a cost-benefit calculation by citizens, arguing that domestic consensus is an important driver of war support. Grieco et al. (2011) argue that citizens present a model of cue-taking from international organizations that is also consistent with a cost-benefit model in that those who exhibit low confidence in the president look abroad for a 'second opinion' on the merits of force (also see Chapman (2009) for a more formal treatment). Similarly, Kull and Destler (1999) hypothesize that international cues are important, arguing that international consensus is key to understanding war support.

Some additional research finds that cues have relatively weak effects. Gelpi (2010) finds that partisanship is not a strong factor in shaping how people perceive the information they receive about the Iraq war. To be sure, there are strong main effects for partisanship but it does appear that party identification serves as a moderator of news about events or of messages from President Bush. Similarly, Nicholson (2010) finds that elite cues have limited power in a series of experiments covering war initiation, support for an ongoing war, and war termination.

Given the mix of results described above, recent research has attempted to explain which elites are important cue-givers and when those cues will be effective. Not surprisingly, the overall information environment (i.e. framing) is central to understanding support for war generally (Aday et al. 2005; Berinsky and Kinder 2006; Boettcher and Cobb 2006; Johnson and Tierney 2006; Johns 2009). This line of research is also beginning to show just how important the news media are for shaping and controlling this information environment (Baum and Groeling 2009; Aday 2010; Althaus and Coe 2011). Whether a member of the political elite can shape public opinion on war depends on who is saying it, what is being said, and the overall information environment in which they are speaking.

The case of British support for the Afghanistan War demonstrates the challenge that parties and leaders can face when it comes to public opinion on matters of war and peace. All three major British parties consistently have maintained that their country's role in combating the Taliban in Afghanistan is vital for eradicating the scourge of international terrorism. These claims notwithstanding, numerous polls indicate that public support for involvement in the conflict is weak and has steadily declined over time, with sizable majorities now saying that the war is not winnable and that British troops should be brought home 'immediately' or 'soon'.8

There are other dispositional and demographic factors that could influence attitude formation about war. Risk orientations are one such factor. When asked about potentially threatening events such as wars, people may consult their general orientations about the desirability of engaging in risky ventures. Accordingly, we conjecture that, ceteris paribus, risk-averse individuals will be less likely to support 
the Afghanistan mission. Socio-demographic characteristics also may be associated with attitudes towards military involvement. Foremost among these variables are gender and age, and we investigate whether often-articulated conjectures that women and young people are more negatively disposed towards international conflict are empirically valid (e.g. Elshtain 1987; Inglehart 1989; Eichenberg 2003; Goldstein 2003; Clements 2012; see also Jenkins-Smith and Herron 2009). We also investigate the impact of ethnicity. Although we do not study the attitudes of specific national groups, we predict that people designating themselves as being of Asian ethnicity will be less supportive of the Afghan conflict. This is because in the British case most of these people have Pakistani, Indian, or Bangladeshi origins. ${ }^{9}$ These are nations with a British colonial heritage, and this history might make these peoples particularly skeptical of a renewed British military presence in the region. In addition, the war has had a direct impact on peace and stability in Pakistan, which shares a long, highly porous border with Afghanistan.

Given the preceding discussion of how the media influence the overall information environment, media consumption is also of interest. The British print media regularly take positions on important political issues, and in the past decade several major newspapers have done so with regard to the wars in Iraq and Afghanistan. Here, we categorize survey respondents by whether they regularly read newspapers that support or oppose British involvement in Iraq, read a newspaper that has not taken a stand, or do not read a newspaper at all. Finally, we consider social class, a variable that traditionally has been accorded pride-of-place in research on mass political behavior in Britain (e.g. Butler and Stokes 1969). Social class may be relevant for understanding views towards the Afghan War because people in different classes may have varying attitudes towards war given their differing propensities to serve in the military or have close family and friends who serve. In addition, factions in the Labour Party and other prominent spokespersons for the working class historically have been closely aligned with disarmament campaigns and pacifist movements (e.g. Vickers 2011). The idea that war is to be resisted because 'workers are ones who fight' has a lengthy history on the British left.

In sum, the heuristics model is:

$$
\begin{aligned}
\text { (Dis) Approval }= & f\left(\beta_{0}+\beta_{1-4} \text { Partyid }+\beta_{5-7} \text { Risk }+\beta_{8} \text { News }+\beta_{9-11}\right. \text { Leaders } \\
& \left.+\beta_{12-14} \text { Ethnicity }+\beta_{15} \text { Gender }+\beta_{16-20} \text { AgeCohort }+\beta_{21} \text { Class }\right)
\end{aligned}
$$

Less parsimonious than its rivals, this model specifies opinions about the war as a function of: (a) four $0-1$ dichotomous variables tapping party identification (reference category = no party identification); (b) three dichotomous variables tapping risk appetite (very accepting, somewhat averse, very averse; reference category = somewhat accepting); (c) newspaper readership (pro, neutral/do not read, con $)^{10} ;(d)$ three 11 -point $(0-10)$ feeling thermometer variables measuring affect for the major party leaders: David Cameron (Conservative), Gordon Brown (Labour) and Nick Clegg (Liberal Democrat); (e) three ethnicity dummy variables (white-non-British, Asian, other; reference category = White British); (f) gender (female $=1$, male $=0$ ); (g) four dichotomous age-cohort variables (reference category $=$ over 65$)$; and $(\mathrm{h})$ social class $(1=$ middle/upper, $0=$ working/lower $)$. 
Figure 1: Approval-Disapproval of British Involvement in the War in Afghanistan

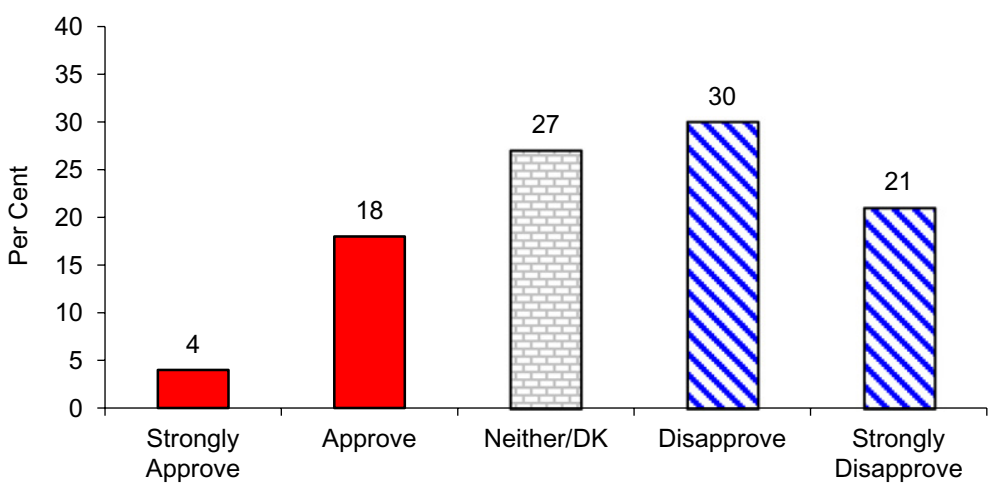

\section{Public Opinion and the Afghanistan War}

Circa February 2009 when our survey was conducted, the British public voiced considerable skepticism about the desirability of their country's involvement in the Afghanistan War. As Figure 1 shows, less than one person in five (18 per cent) approved of the war and less than one in twenty (4 per cent) strongly approved. In contrast, a majority either disapproved or strongly disapproved (30 per cent and 21 per cent, respectively) of British participation in the conflict. An additional onequarter (27 per cent) said either they 'neither approved nor disapproved' or 'didn't know'. This stands in stark contrast to the high levels of public approval for the use of British troops in Afghanistan in the wake of the September 11, 2001 attacks on America. Polls conducted in the initial months of the conflict showed that over 60 per cent of the British public favored British 'boots on the ground'. ${ }^{11}$

Negativity about participation in the war was not confined to particular groups. Rather, majorities or large pluralities in all age, ethnic, gender and social class groupings reported that they either disapproved or strongly disapproved. That said, Figure 2 documents that older persons were more likely to disapprove than were younger ones, with the percentages doing so climbing from 43 per cent among people in the 18-25 age group to fully 64 per cent among those 66 or older. Differences among ethnicity and gender were also substantial, with Asians and women being especially unlikely to approve. Specifically, only 7 per cent of Asians approved as compared to 23 per cent of those saying they were 'White British'. Regarding gender, 13 per cent of women approved of British participation in the war as compared to 32 per cent of men. In contrast, 58 per cent of women but only 44 per cent of men disapproved.

Many people also questioned the prudential basis of the conflict. Large numbers were unconvinced about the benefits of participation, and many were concerned about possible costs. Specifically, only about one person in seven (15 per cent) agreed that Britain would benefit from the war, whereas nearly three in five ( 57 per cent) disagreed (Figure 3). As for costs, only one person in four felt personally threatened by the conflict. However, nearly two in five agreed with that the war 
Figure 2: Approval-Disapproval of British Involvement in the War in Afghanistan by Socio-Demographic Characteristics

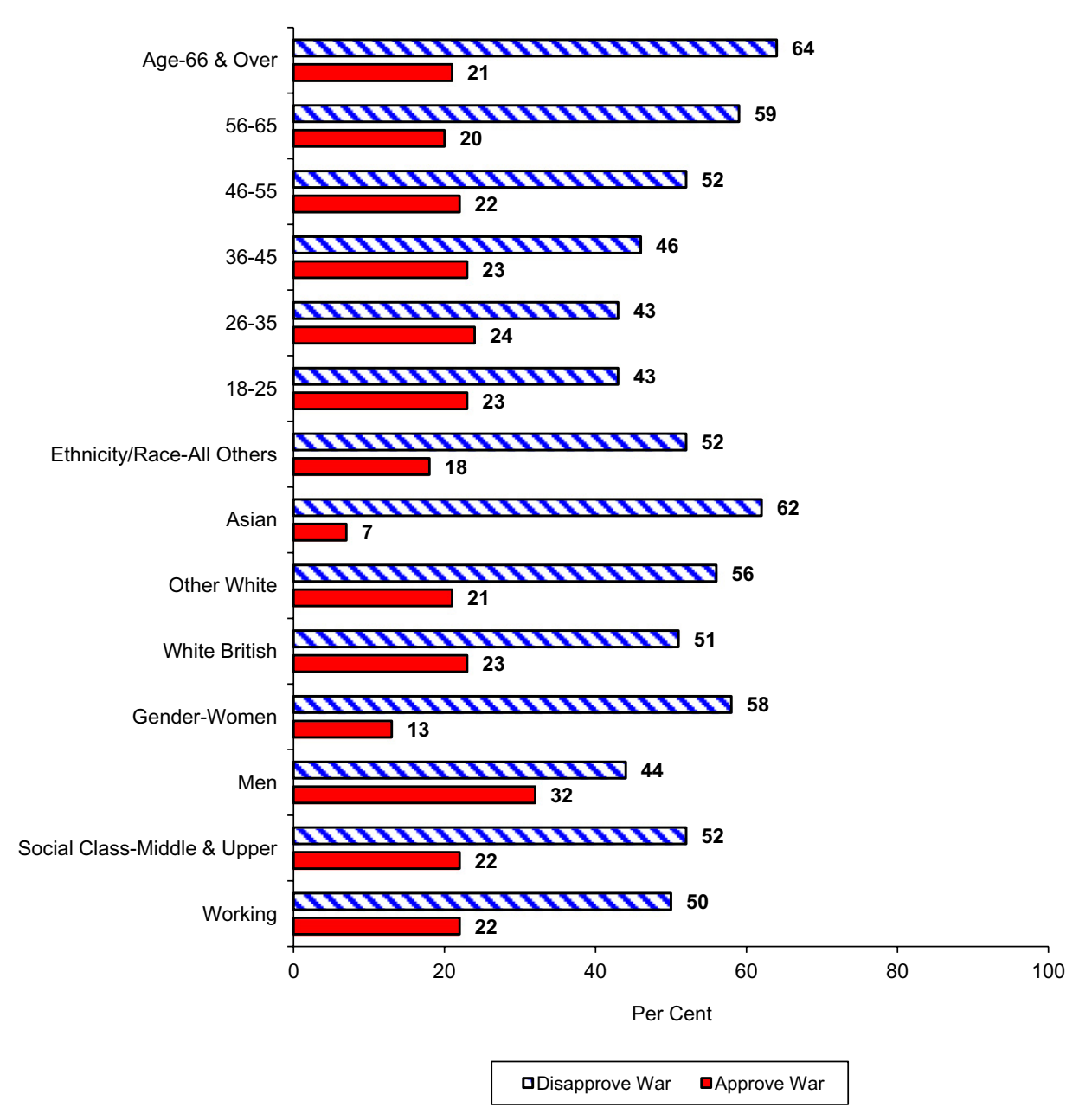

would damage Britain's global interests, and only about one in five disagreed. Nor were people convinced that there was a compelling moral case for military involvement. As Figure 3 shows, a substantial plurality (42 per cent) disagreed with the idea that Britain had a strong moral case for having its military in Afghanistan, and only slightly over one-quarter (28 per cent) agreed with it. Many respondents also expressed doubts about the likelihood that war would have a successful outcome. As Figure 4 illustrates, fully one person in four judged that the war was 'very unlikely' to be successful whereas only one in fifty said the war was 'very likely' to be successful. Overall, the mean score on the 0-10 probability of success scale was a decidedly pessimistic 3.2 .

In sum, the survey data portray a distinct absence of enthusiasm for Britain's military involvement in Afghanistan. Many people expressed combinations of 
Figure 3: Evaluations of the Benefits, Costs and Morality of the War in Afghanistan

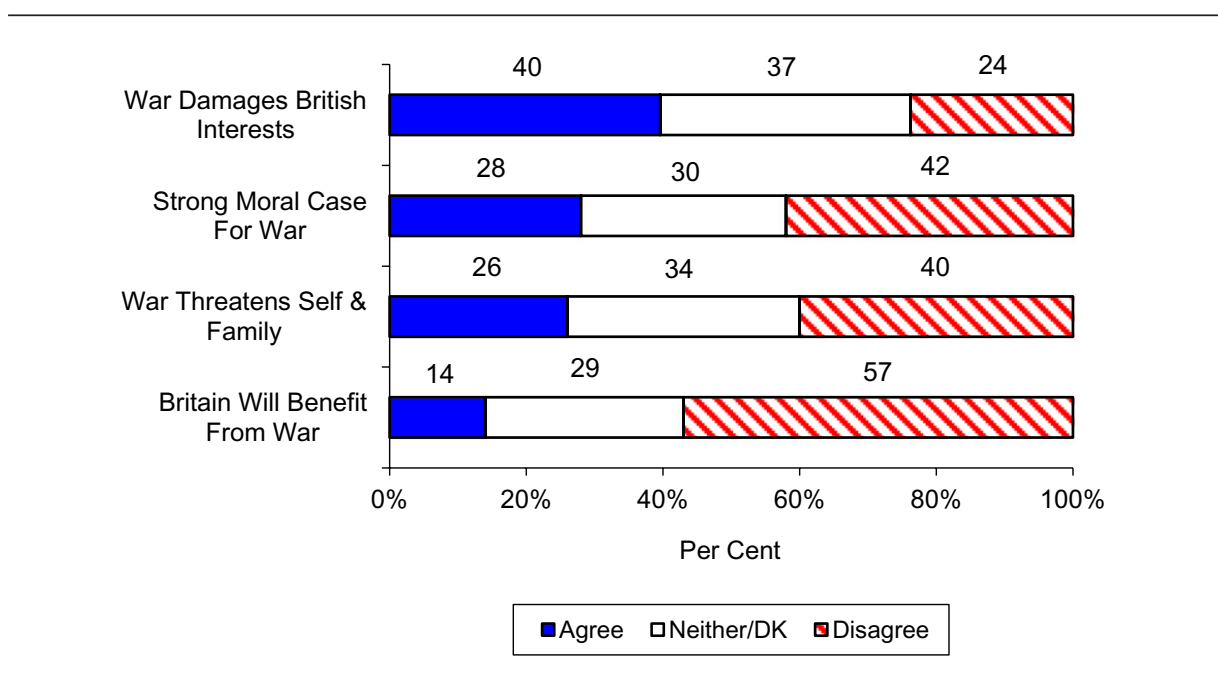

Figure 4: Perceived Likelihood of Winning the War in Afghanistan

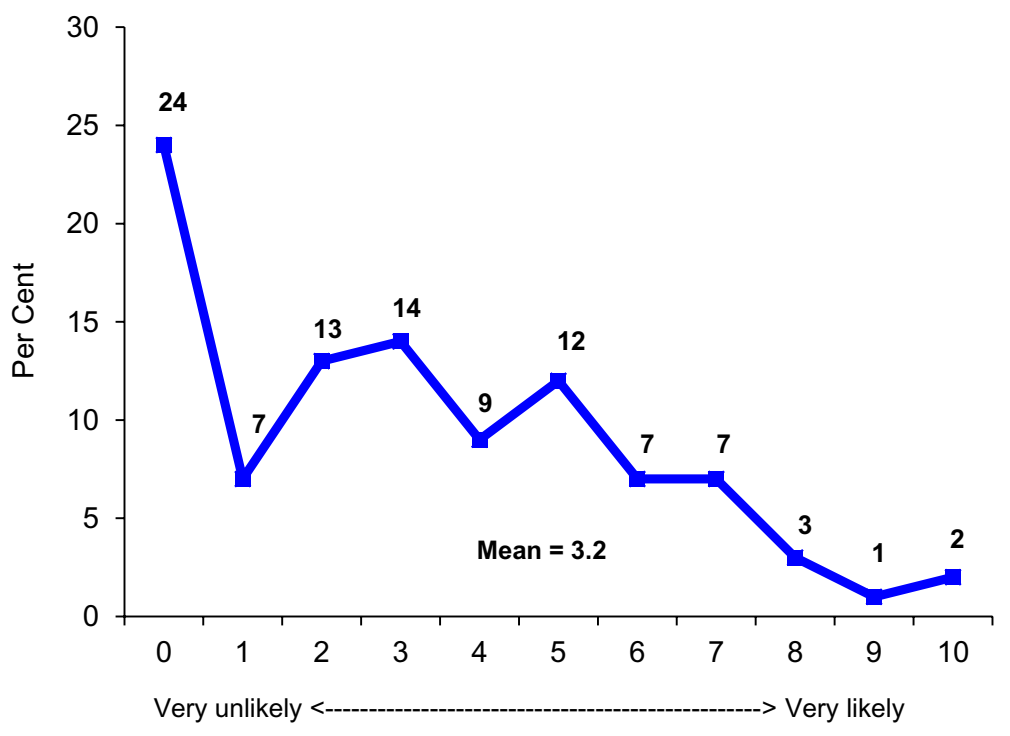

prudential and moral concerns, and a large majority was not sanguine about the eventual outcome of the conflict. Thus, although mainstream political leaders demonstrated continuing unity in their support for British participation in the war since it began in the autumn of 2001, large portions of the public were unconvinced of this often-articulated elite wisdom. In the next section, we investigate the ability 
of the three competing theoretical models discussed above to explain public opinion about the conflict.

\section{Rival Models Considered}

We first consider the performance of the cost-benefits, morality, and general heuristics models separately. Since the dependent variable in the cost-benefit, morality and heuristics models is a five-category ordinal scale, we employ ordinal probit procedures for estimation purposes (e.g. Long and Freese 2006). The results are presented in Table 1 . The cost-benefits model (Model A) fits the data reasonably well with the McKelvey $\mathrm{R}^{2}$ (Long and Freese 2006, 109) being 0.63. As hypothesized, perceived collective benefits discounted by the prospects of success have a significant positive effect $(P<0.001)$ on public opinion about the war. In addition, perceived collective costs are significant $(P<0.001)$ and, as expected, the coefficient is negative. The coefficient for personal costs is also negative, but not significant at conventional levels $(P>0.05)$. Based on these results, low levels of approval for the war can be seen reflecting the fact that few respondents thought the war would end in success and benefit Britain, whereas many believed that involvement would harm their country's global interests.

The morality model also behaves as anticipated, with the $\beta$ coefficient for the predictor variable being statistically significant $(P<0.001)$ and correctly (positively) signed (see Table 1, Model B). The story told by this model is straightforwardrespondents who agreed that there was a strong moral case for Britain's involvement had a significantly higher probability of approving of the conflict. Although the morality model is extremely parsimonious, its explanatory power is quite impressive. The model's McKelvey $\mathrm{R}^{2}$ is 0.63 , exactly the same as that for the cost-benefits model.

Predictors in the heuristics model include party identification, party leader images, risk orientations, newspaper readership, and socio-demographics (age, ethnicity, gender, social class). Table 1 (Model C) shows that several of these variables have statistically significant $(P<0.001)$ and predictable effects on opinion. Specifically, Labour and Conservative identifiers are more likely than nonidentifiers (the reference partisanship category) to endorse military involvement in Afghanistan. Similarly, positive images of Messrs. Brown, Cameron and Clegg, leaders of the three major parties supporting the war, have significant $(P<0.001)$ positive effects, as does readership of a daily newspaper that has endorsed support in the Iraq and Afghanistan conflicts. As also anticipated, highly risk-averse people are significantly $(P<0.001)$ less likely to approve of the conflict. In addition, a number of demographics matter. Women are significantly $(P<0.001)$ less likely to voice support, as are Asians and other non-white British ethnic groups. In contrast, compared to the oldest age group (those over 65), all younger age groups are positively disposed to the war, as are middle class individuals.

Considering model fit, the McKelvey $\mathrm{R}^{2}$ for the general heuristics model is only 0.13 , a considerably smaller value than comparable statistics for the cost-benefits and morality models. Also, considering the full five-category dependent variable varying from 'strongly approve' to 'strongly disapprove', the heuristics model can 
Table 1: Rival Models of Approval-Disapproval of British Involvement in the War in Afghanistan

\begin{tabular}{|c|c|c|c|c|c|c|}
\hline \multirow[b]{3}{*}{ Predictor Variables } & \multicolumn{6}{|c|}{ Model } \\
\hline & \multicolumn{2}{|c|}{ A. Benefits-Costs } & \multicolumn{2}{|c|}{ B. Morality } & \multicolumn{2}{|c|}{ C. Heuristics } \\
\hline & B & s.e. & B & s.e. & B & s.e. \\
\hline \multicolumn{7}{|l|}{ Collective Benefits* } \\
\hline Probability Winning & $0.098^{* * *}$ & 0.001 & & & & \\
\hline Collective Costs & $-0.506^{* * *}$ & 0.010 & & & & \\
\hline Personal Costs & -0.004 & 0.008 & & & & \\
\hline Morality of the War & & & $1.171^{* * *}$ & 0.009 & & \\
\hline \multicolumn{7}{|l|}{ Party Identification: } \\
\hline Labour & & & & & $0.193^{* * *}$ & 0.022 \\
\hline Conservative & & & & & $0.215^{* * *}$ & 0.022 \\
\hline Liberal Democrat & & & & & 0.039 & 0.028 \\
\hline Other Party & & & & & $-0.133^{* * *}$ & 0.030 \\
\hline \multicolumn{7}{|l|}{ Risk Orientation: } \\
\hline Very Acceptant & & & & & -0.015 & 0.032 \\
\hline Somewhat Averse & & & & & -0.005 & 0.016 \\
\hline Very Averse & & & & & $-0.151 * * *$ & 0.026 \\
\hline Newspaper Readership & & & & & $0.042^{* * *}$ & 0.007 \\
\hline \multicolumn{7}{|l|}{ Party Leader Image: } \\
\hline Brown & & & & & $0.093^{* * *}$ & 0.003 \\
\hline Cameron & & & & & $0.017^{* * *}$ & 0.003 \\
\hline Clegg & & & & & $-0.013^{* *}$ & 0.004 \\
\hline \multicolumn{7}{|l|}{ Ethnicity: } \\
\hline White Non-British & & & & & $-0.127^{* * *}$ & 0.041 \\
\hline Asian & & & & & $-0.571^{* * *}$ & 0.087 \\
\hline All 0ther & & & & & $-0.142^{* * *}$ & 0.038 \\
\hline Gender & & & & & $-0.430 * * *$ & 0.015 \\
\hline \multicolumn{7}{|l|}{ Age: } \\
\hline $18-25$ & & & & & $0.530^{* * *}$ & 0.033 \\
\hline $26-35$ & & & & & $0.502^{* * *}$ & 0.033 \\
\hline $36-45$ & & & & & $0.417^{* * *}$ & 0.209 \\
\hline $46-55$ & & & & & $0.287^{* * *}$ & 0.030 \\
\hline $56-65$ & & & & & $0.196^{* * *}$ & 0.028 \\
\hline Social Class & & & & & $0.031^{*}$ & 0.016 \\
\hline Cut Points: 1 & $-1.877^{* * *}$ & 0.040 & $1.854^{* * *}$ & 0.023 & $-0.290 * * *$ & 0.040 \\
\hline 2 & $-0.582^{* * *}$ & 0.038 & $3.254^{* * *}$ & 0.028 & $0.607^{* * *}$ & 0.040 \\
\hline 3 & $0.656^{* * *}$ & 0.039 & $4.521^{* * *}$ & 0.033 & $1.400^{* * *}$ & 0.040 \\
\hline 4 & $2.539 * * *$ & 0.046 & $6.163^{* * *}$ & 0.042 & $2.475^{* * *}$ & 0.043 \\
\hline McKelvey $\mathrm{R}^{2}$ & \multicolumn{2}{|c|}{0.63} & \multicolumn{2}{|c|}{0.63} & \multicolumn{2}{|c|}{0.13} \\
\hline \multicolumn{7}{|l|}{ \% Correctly Classified: } \\
\hline 5 categories & \multicolumn{2}{|c|}{56} & \multicolumn{2}{|c|}{61} & \multicolumn{2}{|c|}{34} \\
\hline 3 categories & \multicolumn{2}{|c|}{71} & \multicolumn{2}{|c|}{73} & \multicolumn{2}{|c|}{51} \\
\hline Log-likelihood & \multirow{2}{*}{\multicolumn{2}{|c|}{$\begin{array}{r}-22646.36 \\
46299.99\end{array}$}} & \multirow{2}{*}{\multicolumn{2}{|c|}{$\begin{array}{r}-23143.00 \\
45302.72\end{array}$}} & -323 & \\
\hline $\mathrm{AIC}^{\dagger}$ & & & & & 621 & \\
\hline $\mathrm{BIC}^{\ddagger}$ & 463 & & & & 623 & \\
\hline
\end{tabular}

$N=21915$

*** $P \leq 0.001$; ** $P \leq 0.01 ; * P \leq 0.05$, one-tailed test.

${ }^{\dagger}$ Akaike Information Criterion, smaller values indicate better model fit

${ }^{\ddagger}$ Bayesian Information Criterion, smaller values indicate better model fit 
only classify 34 per cent of the respondents correctly (Table 1). This compares to 57 per cent for the costs-benefits model, and 61 per cent for the morality model. Collapsing the 'strongly approve' and 'approve' and the 'strongly disapprove' and 'disapprove' categories yields the same pattern; the heuristics model can correctly classify 51 per cent of the cases, whereas the costs-benefits and morality models can correctly classify 71 per cent and 74 per cent, respectively.

Akaike Information Criterion (AIC) and Bayesian Information Criterion (BIC) model selection statistics (Burnham and Anderson 2002) reinforce the conclusion that the cost-benefits and morality models demonstrate superior explanatory power. ${ }^{12}$ For example, the AIC's for the cost-benefits and morality models are 46299.99 and 45302.72 , respectively. These values are substantially smaller (better) than the AIC, 62100.27, for the general heuristics model. The relative magnitudes of the BIC's tell the same story. Although the general heuristics model includes several predictors, it is not able to explain opinions about the war as well as its more parsimonious rivals.

\section{Composite Models}

The preceding analyses suggest that elements of each of the three competing models may help to explain British opinion about their country's military mission in Afghanistan. Although it is valuable to determine which model has the greatest explanatory power, analyzing a composite model containing the variables from all three models can tell us whether-once factors in rival models are controlledvariables in particular models continue to exhibit explanatory purchase.

The results of this analysis (Table 2, Model A) reveal that success-discounted benefits and collective costs continue to exert significant effects, and they are now joined by personal costs. Moral judgments also remain significant. As for the heuristics, the composite model indicates that approval of the war is positively related to being a Conservative partisan, holding a positive image of Prime Minister Gordon Brown, and newspaper readership. Approval of the war is negatively related to being a minor party identifier, being highly risk averse, being a woman, being less than 66 years of age, and being a member of the middle or upper classes. As for overall fit, the composite model is able to correctly classify more cases (64 per cent-five categories and 77 per cent-three categories) and it has a larger McKelvey $\mathrm{R}^{2}(0.75)$ than any of the component models discussed above. Also, despite its richer parameterization, the composite model has a smaller (better) AIC and BIC values.

Although the analysis of the composite model (Table 2, Model A) yields suggestive results, it is possible that parameter estimates are confounded by simultaneity biases involving opinions about the war, on the one hand, and some of the predictor variables, on the other. To address this possibility, we re-estimate the composite model using a two-stage-conditional maximum likelihood (2SCML) technique (Alvarez and Glasgow 1999). Specifically, we consider possible simultaneous relationships involving (dis)approval of the war and party leader images, cost-benefit calculations and judgments regarding the morality of the war. ${ }^{13}$ The 2SCML procedure calls for the residuals from reduced-form first-stage analyses of these 
Table 2: Composite Models of Approval-Disapproval of British Involvement in the War in Afghanistan

\begin{tabular}{|c|c|c|c|c|}
\hline \multirow[b]{3}{*}{ Predictor Variables } & \multicolumn{4}{|c|}{ Model } \\
\hline & \multicolumn{2}{|c|}{ A. Recursive } & \multicolumn{2}{|c|}{ B. $2 S C M L$} \\
\hline & B & s.e. & B & s.e. \\
\hline \multicolumn{5}{|l|}{ Collective Benefits* } \\
\hline Probability Winning & $0.063^{* * *}$ & 0.001 & $0.062^{* * *}$ & 0.001 \\
\hline Collective Costs & $-0.375^{* * *}$ & 0.010 & $-0.658^{* * *}$ & 0.044 \\
\hline Personal Costs & $-0.023^{* *}$ & 0.008 & $-0.018^{*}$ & 0.008 \\
\hline Morality of the War & $0.849 * * *$ & 0.011 & $0.848^{* * *}$ & 0.001 \\
\hline \multicolumn{5}{|l|}{ Party Identification: } \\
\hline Labour & 0.020 & 0.024 & -0.011 & 0.024 \\
\hline Conservative & $0.108^{* * *}$ & 0.025 & $0.070^{* *}$ & 0.025 \\
\hline Liberal Democrat & 0.019 & 0.031 & 0.026 & 0.031 \\
\hline Other Party & $-0.134^{* * *}$ & 0.033 & $-0.127^{* * *}$ & 0.033 \\
\hline \multicolumn{5}{|l|}{ Risk Orientation: } \\
\hline Very Acceptant & -0.021 & 0.036 & -0.016 & 0.036 \\
\hline Somewhat Averse & 0.017 & 0.018 & 0.020 & 0.018 \\
\hline Very Averse & $-0.089 * *$ & 0.029 & $-0.062^{*}$ & 0.029 \\
\hline Newspaper Readership & $0.026^{* * *}$ & 0.007 & $0.017^{* *}$ & 0.007 \\
\hline \multicolumn{5}{|l|}{ Party Leader Image: } \\
\hline Brown & $0.013^{* * *}$ & 0.004 & -0.002 & 0.004 \\
\hline Cameron & -0.002 & 0.004 & -0.001 & 0.004 \\
\hline Clegg & -0.003 & 0.005 & -0.004 & 0.005 \\
\hline \multicolumn{5}{|l|}{ Race/Ethnicity: } \\
\hline White Non-British & 0.019 & 0.045 & 0.017 & 0.045 \\
\hline Asian & $-0.483^{* * *}$ & 0.097 & $-0.384^{* * *}$ & 0.098 \\
\hline All Other & -0.031 & 0.037 & -0.008 & 0.037 \\
\hline Gender & $-0.283^{* * *}$ & 0.017 & $-0.220^{* * *}$ & 0.019 \\
\hline \multicolumn{5}{|l|}{ Age: } \\
\hline $18-25$ & $0.311^{* * *}$ & 0.037 & $0.253^{* * *}$ & 0.038 \\
\hline $26-35$ & $0.301^{* * *}$ & 0.033 & $0.248^{* * *}$ & 0.034 \\
\hline $36-45$ & $0.297^{* * *}$ & 0.033 & $0.246^{* * *}$ & 0.034 \\
\hline $46-55$ & $0.184^{* * *}$ & 0.033 & $0.142^{* * *}$ & 0.034 \\
\hline $56-65$ & $0.150^{* * *}$ & 0.032 & $0.126^{* * *}$ & 0.032 \\
\hline Social Class & $0.040^{* *}$ & 0.017 & 0.028 & 0.017 \\
\hline Collective Costs Residuals & $X X$ & $X X$ & $0.286^{* * *}$ & 0.043 \\
\hline Cut Points: 1 & $0.263^{* * *}$ & 0.064 & $-0.729 * * *$ & 0.162 \\
\hline 2 & $1.900^{* * *}$ & 0.065 & $0.910^{* * *}$ & 0.161 \\
\hline 3 & $3.451^{* * *}$ & 0.068 & $2.465^{* * *}$ & 0.161 \\
\hline 4 & $5.617^{* * *}$ & 0.074 & $4.625^{* * *}$ & 0.165 \\
\hline McKelvey $\mathrm{R}^{2}$ & \multicolumn{2}{|c|}{0.75} & \multicolumn{2}{|c|}{0.75} \\
\hline \multicolumn{5}{|l|}{$\%$ Correctly Classified: } \\
\hline 5 categories & \multicolumn{2}{|c|}{64} & \multicolumn{2}{|c|}{64} \\
\hline 3 categories & \multicolumn{2}{|c|}{77} & \multicolumn{2}{|c|}{77} \\
\hline Log-likelihood & \multicolumn{2}{|c|}{-19406.34} & \multicolumn{2}{|c|}{-19383.93} \\
\hline $\mathrm{AIC}^{\dagger}$ & \multirow{2}{*}{\multicolumn{2}{|c|}{$\begin{array}{l}38870.68 \\
39102.54\end{array}$}} & \multicolumn{2}{|c|}{38827.85} \\
\hline $\mathrm{BIC}^{\ddagger}$ & & & \multicolumn{2}{|c|}{39069.70} \\
\hline
\end{tabular}

$N=21915$

*** $P \leq 0.001$; ** $P \leq 0.01$; $P \leq 0.05$, one-tailed test

${ }^{\dagger}$ Akaike Information Criterion; smaller values indicate better model fit

${ }^{\ddagger}$ Bayesian Information Criterion; smaller values indicate better model fit

$\mathrm{XX}$, variable not included in model 
variables to be incorporated on the right-hand side of a second-stage model of opinions about the war (see Alvarez and Glasgow 1999). Significant residuals provide evidence of simultaneity bias. Including residuals for models of party leaders, costs, benefits and morality variables in the composite model reveals that the only significant effect is associated with collective costs $(t=3.12, P<0.002)$. Accordingly, we re-estimate the composite model including the collective costs residuals together with other predictors.

An analysis of this revised composite model (Table 2, Model B) indicates that elements of each of the three theoretical models continue to contribute to explaining opinions about the war. The coefficient for success discounted collective benefits remains statistically significant $(P<0.001)$ and positive, while collective costs continue to exert significant $(P<0.001)$ and properly (negatively) signed effects. Personal costs remain significant $(P<0.05)$ and negatively signed as well. Beliefs about the morality of the conflict remain positive and statistically significant too $(P<0.001)$. Variables from the heuristics model also continue to matter, with Conservative partisanship rather than affect for the party's leader, David Cameron, achieving statistical significance. In contrast, identification with the Labour Party has no influence on support for the British mission, and affect for Prime Minister Gordon Brown is now statistically insignificant as well. These latter findings may reflect the fact that the Conservative Party has consistently expressed unified support for British involvement in the Iraq and Afghanistan wars. In contrast, although Labour Prime Minister Gordon Brown, like his predecessor Tony Blair, strongly backed the Afghan mission, Labour was deeply split in the former case, and many Labour elites and activists expressed only tacit support in the latter one. Other statistically significant $(P<0.05)$ predictors include minor party identification, gender, risk aversion, newspaper readership, Asian ethnicity, and age group (see Table 2, Model B). Social class is now insignificant.

Overall, the fit of the 2 SCML model is very similar to the basic composite model; the McKelvey $\mathrm{R}^{2}$ remains 0.75 , and the percentages of cases correctly classified are 64 per cent (five categories) and 77 per cent (three categories). The AIC for the $2 \mathrm{SCML}$ model again indicates that a composite specification is superior to any of the three competing models considered separately.

Given the non-linear nature of the probit functional form, it is difficult to discern the substantive impact of various predictor variables. Accordingly, Table 3 reports analyses that illustrate the size of the effects of various statistically significant predictors in the 2SCML composite model. In these analyses, we compute changes in the probability of approving or strongly approving of the war as we shift each significant predictor in turn from its minimum to its maximum value holding other continuous variables at their means and other dichotomous variables at $0 .{ }^{14}$ The results reveal that collective benefits discounted by likelihood of success, collective costs and normative judgments all exert substantively impressive effects on opinions about the war. Specifically, variations in these three predictors can change the probability of approving the war (on a $0-1$ scale) by $0.87,-0.48$ and 0.67 points, respectively. In contrast, the impact of personal costs is substantively trivial $(-0.01$ points). All of the effects associated with predictors in the heuristics model also are very small. Their average ability to change approval of the war is only 0.02 points 


\section{Table 3: Changes in Probabilities of Approval of British Involvement in the War in Afghanistan Associated with Changes ${ }^{\dagger}$ in Statistically Significant Predictor Variables}

\begin{tabular}{|c|c|c|c|}
\hline \multirow{2}{*}{ Collective Benefits* } & \multirow[t]{2}{*}{$\begin{array}{l}\text { Change in } \\
\text { Probability }\end{array}$} & \multicolumn{2}{|c|}{$\begin{array}{c}95 \% \\
\text { Confidence } \\
\text { Interval }\end{array}$} \\
\hline & & & \\
\hline Probability Winning & 0.871 & 0.836 & 0.908 \\
\hline Collective Costs & -0.478 & -0.553 & -0.397 \\
\hline Personal Costs & -0.007 & -0.014 & 0.001 \\
\hline Morality of the War & 0.669 & 0.648 & 0.709 \\
\hline \multicolumn{4}{|l|}{ Party Identification: } \\
\hline Conservative & 0.006 & 0.000 & 0.012 \\
\hline Other Party & -0.011 & -0.017 & -0.004 \\
\hline \multicolumn{4}{|l|}{ Risk Orientation: } \\
\hline Very Averse & -0.006 & -0.012 & -0.000 \\
\hline \multicolumn{4}{|l|}{ Newspaper Readership } \\
\hline \multicolumn{4}{|l|}{ Race/Ethnicity: } \\
\hline Asian & -0.029 & -0.044 & -0.009 \\
\hline Gender & -0.023 & -0.027 & -0.018 \\
\hline \multicolumn{4}{|l|}{ Age: } \\
\hline $18-25$ & 0.026 & 0.015 & 0.038 \\
\hline $26-35$ & 0.022 & 0.015 & 0.029 \\
\hline $36-45$ & 0.023 & 0.016 & 0.031 \\
\hline $46-55$ & 0.009 & 0.003 & 0.016 \\
\hline $56-65$ & 0.008 & 0.002 & 0.014 \\
\hline
\end{tabular}

(absolute value), with the largest effect $(-0.03)$ being associated with membership in the Asian race/ethnicity category. ${ }^{15}$ Taken together, these results emphasize the importance of judgments about collective costs and benefits and moral concerns as factors affecting public opinion on Britain's military involvement in Afghanistan.

\section{The Case of British Military Involvement in Libya}

As an additional test of the ability of the cost-benefits, morality and heuristics models to explain public opinion towards the use of military force, we investigate their ability to account for reactions to British involvement in the recent multilateral action against Colonel Muammar Gaddafi's regime in Libya. British involvement against the Gaddafi regime occurred in a political-economic context quite 
different from that which had obtained when the decision was made to employ military forces in Afghanistan. In late winter 2011, the British economy was suffering from the effects of the world economic crisis and a newly elected Conservative-Liberal Democrat coalition government had replaced Labour. Led by Conservative Prime Minister David Cameron, the Coalition announced its determination to address the country's growing sovereign debt with painful austerity policies designed to sharply reduce public sector spending. Given the straightened economic circumstances and continuing, decade-long, military involvement in Afghanistan, the Coalition Government's ability to marshal public support for even a minimal armed intervention in the Libyan conflict was problematic.

To study the determinants of British public opinion about military engagement in Libya, we employ data gathered in the March and April 2011 monthly BES-CMS surveys. ${ }^{16}$ These surveys contained identical batteries of questions to those discussed above in the analyses of determinants of public opinion about British military involvement in Afghanistan. The sole exception was that a new question regarding the affordability of a military action against Gaddafi was substituted for the question about personal threats posed by the operation. ${ }^{17}$

Before presenting the results of the tests of the rival models, we observe that British military involvement in Libya did not have broad public support. Conducted only a few days after hostilities were initiated on 19 March, the March 2011 CMS reveals that only 30 per cent approved of British military involvement whereas a plurality 44 per cent disapproved. The operation was even less popular a month later, with less than one-quarter ( 23 per cent) of the April CMS respondents approving and half ( 50 per cent) disapproving. Nor did the public believe there were collective benefits to be gained from participating-in March only 16 per cent thought that Britain would benefit in the long run and in April, only 13 per cent did so. Sizable majorities also were worried about the costs of the operation, with 61 per cent in March and 65 per cent in April stating that they did not think Britain could afford military action against Libya. Nor was there a consensus about the existence of a strong moral case for the action. In March 41 per cent agreed that there was such a case, but 34 per cent disagreed. In April the percentage agreeing there was a strong moral case had fallen to 31 per cent, with 37 per cent disagreeing. Finally, many people were not convinced that Britain could carry out the operation successfully. When respondents were asked to use a 0-10 scale with 0 meaning 'complete failure' and 10 meaning 'complete success' to evaluate the likelihood that the operation would succeed, the mean score was only 4.7 in March and 4.2 in April.

Table 4 summarizes ordinal probit analyses of the benefits-costs, morality and heuristics models of approval-disapproval of British involvement in the military action in Libya using the pooled March and April 2011 CMS data. Except for the substitution of the 'affordability' item for personal costs in the benefits-costs model and an alternative measure of risk acceptance-aversion, ${ }^{18}$ all predictor variables in the three models are identical to those used in the analyses of attitudes towards Afghanistan presented earlier. The results of the Libya analyses are very similar to those earlier analyses-the benefits-costs and morality models exhibit strong explanatory power and the heuristics model performs quite poorly. Specifically, McKelvey $\mathrm{R}^{2}$ statistics for the benefits-costs and morality models are 0.67 and 0.60 , 
Table 4: Rival Models of Approval-Disapproval of British Involvement in Military Action Against Libya, March and April 2011 BES-CMS Surveys

\begin{tabular}{|c|c|c|c|c|c|c|}
\hline \multirow[b]{3}{*}{ Predictor Variables } & \multicolumn{6}{|c|}{ Model } \\
\hline & \multicolumn{2}{|c|}{ A. Benefits-Costs } & \multicolumn{2}{|c|}{ B. Morality } & \multicolumn{2}{|c|}{ C. Heuristics } \\
\hline & $B$ & s.e. & $B$ & s.e. & $B$ & s.e. \\
\hline \multicolumn{7}{|l|}{ Collective Benefits* } \\
\hline Probability Winning & $0.090^{* * *}$ & 0.003 & & & & \\
\hline \multicolumn{7}{|l|}{ Collective Costs: } \\
\hline Damage British Interests & $-0.488^{* * *}$ & 0.028 & & & & \\
\hline Britain Can't Afford & $-0.289 * * *$ & 0.030 & & & & \\
\hline Morality of the Action & & & $1.043^{* * *}$ & 0.027 & & \\
\hline \multicolumn{7}{|l|}{ Party Identification: } \\
\hline Labour & & & & & 0.099 & 0.073 \\
\hline Conservative & & & & & 0.046 & 0.076 \\
\hline Liberal Democrat & & & & & 0.135 & 0.094 \\
\hline Other Party & & & & & $-0.146^{*}$ & 0.089 \\
\hline Risk Orientation & & & & & $0.030^{* *}$ & 0.010 \\
\hline Newspaper Readership & & & & & 0.021 & 0.022 \\
\hline \multicolumn{7}{|l|}{ Party Leader Image: } \\
\hline Miliband & & & & & $0.046 * * *$ & 0.011 \\
\hline Cameron & & & & & $0.058^{* * *}$ & 0.013 \\
\hline Clegg & & & & & 0.020 & 0.012 \\
\hline \multicolumn{7}{|l|}{ Ethnicity: } \\
\hline White Non-British & & & & & 0.006 & 0.130 \\
\hline Asian & & & & & $-0.460^{* * *}$ & 0.153 \\
\hline All Other & & & & & -0.043 & 0.130 \\
\hline Gender & & & & & $-0.302^{* * *}$ & 0.047 \\
\hline \multicolumn{7}{|l|}{ Age: } \\
\hline $18-15$ & & & & & 0.017 & 0.106 \\
\hline $26-35$ & & & & & $0.243^{* *}$ & 0.091 \\
\hline $36-45$ & & & & & -0.086 & 0.093 \\
\hline $46-55$ & & & & & -0.062 & 0.092 \\
\hline $56-65$ & & & & & -0.126 & 0.126 \\
\hline Social Class & & & & & -0.035 & 0.087 \\
\hline Cut Points: 1 & $-2.974^{* * *}$ & 0.154 & $1.832^{* * *}$ & 0.074 & $-0.341^{* *}$ & 0.146 \\
\hline 2 & $-1.812^{* * *}$ & 0.147 & $2.932^{* * *}$ & 0.084 & $0.347^{* *}$ & 0.146 \\
\hline 3 & $-0.523^{* * *}$ & 0.144 & $4.117^{* * *}$ & 0.100 & $1.100^{* * *}$ & 0.147 \\
\hline 4 & $1.208 * * *$ & 0.153 & $5.565^{* * *}$ & 0.120 & $2.139 * * *$ & 0.151 \\
\hline McKelvey $\mathrm{R}^{2}$ & \multicolumn{2}{|c|}{0.67} & \multicolumn{2}{|c|}{0.60} & \multicolumn{2}{|c|}{0.09} \\
\hline \multicolumn{7}{|l|}{ \% Correctly Classified: } \\
\hline 5 categories & \multicolumn{2}{|c|}{61} & \multicolumn{2}{|c|}{58} & \multicolumn{2}{|c|}{29} \\
\hline 3 categories & \multicolumn{2}{|c|}{74} & \multicolumn{2}{|c|}{71} & \multicolumn{2}{|c|}{39} \\
\hline Log-likelihood & \multicolumn{2}{|c|}{-2219.58} & \multicolumn{2}{|c|}{-2366.26} & \multicolumn{2}{|c|}{-3160.82} \\
\hline $\mathrm{AIC}^{\dagger}$ & 445 & & 474 & & 636 & \\
\hline $\mathrm{BIC}^{\ddagger}$ & 449 & & 477 & & 649 & \\
\hline
\end{tabular}

$N=2145$

*** $P \leq 0.001$; ** $P \leq 0.01$; $P \leq 0.05$; one-tailed test

${ }^{\dagger}$ Akaike Information Criterion; smaller values indicate better model performance

${ }^{\ddagger}$ Bayesian Information Criterion; smaller values indicate better model performance 
respectively, whereas for the heuristics model the value is only 0.09. Similarly, the percentages of respondents correctly classified across the five approve-disapprove categories of the dependent variable decrease from 61 per cent for the benefits-costs model to 58 per cent for the morality model to 29 per cent for the heuristics model. For the more general three-category classification, these percentages are 74 per cent, 71 per cent and 39 per cent, respectively. Finally, similar to the Afghanistan analyses, the AIC and BIC model selection statistics for the benefits-costs and morality models are smaller than that for the heuristics model, thereby indicating that the former two models outperform the latter one.

Regarding individual predictors, Table 4 shows that all of the variables in the benefits-costs and morality model have statistically significant $(P<0.001)$ and correctly signed effects. In the heuristics model, several predictors also are significant $(P<0.05$ or less) including two of the three leader image variables (Cameron and Miliband). These variables have positive effects on attitudes towards the Libya action. The analysis also shows that minor party identifiers, men and risk-acceptant persons are more likely to favor action, whereas persons of Asian ethnicity and those in the 26-35 age bracket are more likely to oppose it.

Similar to the Afghanistan analyses, we next analyze a composite model of attitudes towards the military intervention in Libya that contains all of the predictors in the three individual models. The results (not shown in tabular form) again resemble the Afghanistan case. Specifically, the composite model outperforms the individual models, exhibiting the largest McKelvey $\mathrm{R}^{2 \prime} \mathrm{s}(.76)$, the largest percentage of cases correctly classified (five category: 65 per cent; three category: 77 per cent), and the smallest (best) model selection values $(\mathrm{AIC}=3874.54$; $\mathrm{BIC}=4027.65)$. Regarding individual predictors in the composite models, all of the benefits-costs and morality variables remain statistically significant $(P<0.001)$ and properly signed. However, none of the leader image variables approach conventional levels of statistical significance (i.e., $P>0.10$ ).

Viewed generally, the analyses of the Libyan data bear very strong similarities to those for Afghanistan. In both cases the benefits-costs and morality models exhibit relatively strong explanatory power and the heuristics model fares quite poorly. The latter's explanatory contributions are not wholly absent, but they are marginal once the effects of benefits-costs and morality predictors are taken into account. The failure of leader heuristics to exert strong effects is particularly noticeable in both sets of analyses. The reductions of these effects to statistical insignificance or marginality in the composite models suggest that, to the extent that leader heuristics mattered in the Afghanistan and Libya cases, their effects are almost wholly indirect. Unlike Iraq, Britain's involvement in military actions in Afghanistan and Libya were both instances where party leaders were agreed that British participation was desirable. This pattern, in turn, suggests that the extent of inter-elite consensus may mediate the strength of the effects of leader heuristics on public opinion about the use of military force. We return to this topic in the conclusion.

The negligible role party identification and leader images have on support for the British interventions in Afghanistan and Libya contrasts with the significant impact Clarke et al. (2009b) found partisan and leader cues played in shaping public opinion towards the Iraq War. In one sense, the discrepancy in findings does not 
surprise as elite and party positions were divided on the former while unified on the latter. However, negative attitudes towards the British missions, particularly in Afghanistan, remain a curiosity because it is a situation where, although their reasoning sometimes differed, elites from all three major parties presented a near unified voice in expounding the importance of British military engagement in the region.

\section{Leaders, Parties and an Afghanistan Surge: An Experimental Assessment}

A potential criticism of the preceding findings about the weakness of party and leader heuristics is one applicable to all statistical analyses of observational data, namely that the analyses do not directly test the ability of elite cues to move public opinion. Rather, the multivariate analyses demonstrate whether partisan identifications and leader images are significantly associated with variations in support for British military operations when statistical controls for other theoretically interesting covariates are applied. Here, we address this concern by conducting a survey experiment regarding possible British participation in a military surge in Afghanistan.

As noted above, the outlook in Afghanistan was anything but positive when our survey was fielded in 2009 and new strategies were being considered. One such strategy that had seen success in Iraq was the 'surge' of 2007, which involved a focus on counter-insurgency combined with a significant escalation in the number of troops on the ground. The result was a marked decline in the sectarian violence that was threatening to become a full-blown civil war (Ricks 2009; Sky 2011). Given its success, it seemed plausible that a similar surge could turn the tide in Afghanistan.

In our survey experiment, a control group of 1,111 respondents were given information concerning a hypothetical surge of British troops in Afghanistan that reads as follows: 'Britain presently has 8000 troops fighting the Taliban in Afghanistan. There is a proposal to send an additional 2000 British troops to Afghanistan. Do you approve or disapprove of sending additional troops to Afghanistan?'19 Support for this action was markedly low, with only 18 per cent approving and 65 per cent disapproving (the remainder were unsure or did not know).

Other respondents were randomly assigned to a number of treatment conditions, the first four of which indicated that the either Gordon Brown or David Cameron supported or opposed the action. In the first set of experiments, the only condition to produce a response distribution discernibly different from the control group was the treatment group who were told then Opposition Leader David Cameron supported the action. In this instance, support for the surge rose slightly to 23 per cent of the respondents and opposition fell to 60 per cent. ${ }^{20}$

The second set of treatments set up a scenario where the Prime Minister and Leader of the Opposition took opposing stances on the surge. The distributions of responses from the treatment suggesting that Gordon Brown supported the action with David 
Cameron in opposition were not significantly different from one another. However, when Cameron is in support of the policy, support again rose very slightly-to 21 per cent. ${ }^{21}$

Additional treatments mentioned parties instead of party leaders. The results resemble those for the leader treatments just described. Specifically, respondents receiving treatments mentioning either the Labour or the Conservative parties' stances had response distributions that were not statistically different from those for the control group. The two groups of respondents who were told either: (i) the Conservatives support the surge or (ii) the Conservatives support the surge but Labour opposes it were both significantly but only slightly more supportive of the action than was the control group. The former group (Group i) had 19 per cent who supported the surge and 62 per cent who opposed it and the latter group (Group ii) had 22 per cent who supported the surge and 64 per cent who opposed.

Overall, the very weak treatment effects in the survey experiment are consistent with the results from the multivariate statistical analyses of factors affecting public attitudes towards British military involvement in Afghanistan and Libya. The direct effects of elite cues range from negligible to very modest.

\section{Conclusion: When Heuristics Fail}

Recent scholarship is divided on the primary drivers of public opinion on war. Although some analysts argue that opinion can be modeled as a cost-benefits calculation, others argue that judgments about the morality of a conflict are paramount, and still others maintain that public opinion is guided largely by cues such as those provided by political leaders and other elites. Above, we have used data gathered in a 2009 national survey to investigate the ability of these three competing models to explain public opinion about Britain's military involvement in Afghanistan. Additional analyses of the explanatory power of these models used 2011 survey data on public attitudes regarding British military support for Libyan rebels attempting to overthrow Muammar Qaddafi. In addition, we reported the results of a survey experiment that investigated if partisan and leader image cues affected levels of support for a possible British military surge in Afghanistan. The multivariate analyses of the Afghan and Libyan cases demonstrate that both the cost-benefit calculations and normative considerations have strong effects. In contrast, the impacts of various heuristics are much weaker. Leader images, partisanship, media consumption patterns, risk acceptance/aversion, and various sociodemographics including gender, age, ethnicity and social class all fail to account for variations in opinion about the Afghanistan and Libyan cases. The weakness of party and leader cues is also apparent in the experiment concerning possible effects of these cues on support for a military surge in Afghanistan. Taken together, these several results testify that a combination of prudence and principle were the main drivers of British public opinion about military involvement in Afghanistan and Libya. Affective cues and other heuristics mattered (much) less.

Present findings suggest interesting avenues for future research. Analyses demonstrating that prudential and principled considerations both have sizable effects on public opinion about Britain's military actions in Afghanistan and Libya echo results 
of a recent study of attitudes toward British participation in the Iraq War. ${ }^{22}$ Whether combinations of principle and prudence also work in tandem to provide strong explanations of public opinion in other countries about other wars is an intriguing research question.

The failure of elite cues to exert sizable effects on public opinion in the Afghan and Libyan cases is also interesting and suggestive. Research has repeatedly indicated that leader and partisan heuristics strongly influence electoral choice in Britain and elsewhere, ${ }^{23}$ but their impact on public opinion about war and international affairs more generally are less well understood. The Afghanistan case is one where weak to negligible leader and partisan effects on public opinion about the war occurred in a context characterized by longstanding elite consensus on the desirability of British military involvement in that country. There was a similar elite consensus, albeit of much shorter and more recent vintage, regarding British participation in NATO strikes against the Gaddafi regime in Libya. Again, leader heuristics had a negligible influence in models of public opinion about the desirability of British involvement in those strikes. These results contrast sharply with the presence of sizable leader and partisan effects on British public opinion on the Iraq War-a conflict characterized by acrimonious, protracted and widely publicized divisions in elite opinion. ${ }^{24}$ The conjecture that the strength of leader and partisan cues on public opinion about war is animated by the intensity of inter-elite conflict merits additional inquiry in Britain and elsewhere.

\section{About the Authors}

Jason Reifler, Political Science, Georgia State University, PO Box 4069 Atlanta, GA 30302-4069, USA, email: jreifler@gsu.edu

Harold D. Clarke, School of Economic, Political and Policy Sciences, University of Texas at Dallas, 800 West Campbell Road, Richardson, TX 75080-3021, USA, email: clarke475@msn.com

Thomas J. Scotto, Department of Government, University of Essex, Wivenhoe Park, Colchester, Essex CO4 3SQ, UK, email: tscott@essex.ac.uk

David Sanders, Department of Government, University of Essex, Wivenhoe Park, Colchester, Essex CO4 3SQ, UK, email: sanders@essex.ac.uk

Marianne C. Stewart, School of Economic, Political and Policy Sciences, University of Texas at Dallas, 800 West Campbell Road, Richardson, TX 75080-3021, USA, email: mstewart@utdallas.edu

Paul Whiteley, Department of Government, University of Essex, Wivenhoe Park, Colchester, Essex CO4 3SQ, UK, email: whiteley@essex.ac.uk

\section{Notes}

1. However, see also Gelpi et al. 2009 for extensive survey data generated specifically to examine war support generally and support for the Iraq War specifically.

2. The 2010 British Election Study data are available at http://bes2009-10.org. Fieldwork for the CMS surveys containing the batteries of questions on public opinion about British involvement in the wars in Afghanistan and Libya were conducted by YouGov PLC. For analyses documenting the representative nature of the BES, CMS and other high quality internet surveys, see Sanders et al. 2007; Clarke et al. 2008; Ansolabehere and Schaffner 2011. Dr Scotto's time on the project was supported by ESRC Grant RES-061-25-0405. Data collection was supported by a British Academy Small Grant (\#SG-47045) awarded to Drs Scotto and Reifler. 
3. Although there are some exceptions, costs typically are measured by the number of military personnel killed. In analyses of cross-sectional survey data gathered over a period of a few days such as those we employ here the number of casualties is basically constant. Accordingly, the models we specify do not use casualties as a measure of costs.

4. To be clear, we are not saying that existing cost-benefit models ignore benefits. Rather, we argue that the typical approach of using mission goal (broadly defined) as a proxy for benefits presents significant and underappreciated problems in understanding what citizens expect to gain from war, and therefore in constructing cost-benefit models. Previous research has overwhelmingly shown that some types of missions garner more support than others (e.g. Jentleson 1992; Herrmann et al. 1999; and Gelpi et al. 2009, ch. 4). These differences in support-whether seen in survey marginals for different military actions or across experimental treatments-strongly imply that citizens are thinking about why their country (the United States) is going to war. Nonetheless, inferences about the benefits that citizens perceive are indirect. To illustrate, suppose the United States is suddenly confronted with the choice of whether to engage in a military operation to dislodge the advancing armies of 'Attackalot' from 'Peaceonia'. This type of foreign policy restraint mission is the sort likely to generate fairly high levels of support in experimental research. At the same time, we still have remarkably little understanding into exactly why people support this type of mission. They may see a clear and present danger posed by Attackalot, and military involvement safeguards their person, family, or immediate community. Or, support could be driven belief in a slightly more diffuse benefit that stopping aggression leads to greater safety (either from Attackalot specifically, or by successful deterrence more generally). Perhaps support is driven by an abstract belief that wrongdoers should be punished, which means that the benefit received is retribution exacted on Attackalot. Alternately, the benefit that leads to support for a war liberating Peaceonia is to restore freedom or to end the suffering that comes with conquest. Analyses presented in this article are designed to encourage additional research on various benefits that citizens see coming from war.

5. This approach is consistent with models of attitude formation which posit that perceived benefits are not important unless citizens believe they will be attained (e.g. Ajzen and Fishbein 1980).

6. We illustrate question wordings using questions asked about the British participation in the Afghanistan War. Wording for questions asked about the conflict in Libya are cited in note 17 below.

7. The question wording is: 'Please tell me whether you strongly approve, approve, disapprove, or strongly disapprove of Britain's involvement in the war against the Taliban in Afghanistan?'

8. See YouGov Afghanistan tracker surveys: http://today.yougov.ac.uk/archives/politics/trackers.

9. It is not possible to investigate the impact of religion since variables measuring religious affiliation and religiosity are not included in the CMS surveys.

10. Respondents who read a daily newspaper taking a pro-war stand were coded +1 ; those who read a daily newspaper taking an anti-war stand were coded -1 , and all other respondents were coded 0 . Pro-war newspapers included the Daily Mail and the Scottish Daily Mail, Express, Scotsman, Sun, Telegraph, and Times. Anti-war newspapers included the Daily Record, Guardian, Independent, Mirror, and Scottish Mirror.

11. See Kriner and Wilson 2010 for a discussion of over-time trends in public approval of the British intervention in Afghanistan.

12. The AIC and BIC model selection criteria include discounts for the richness of model parameterization. The AIC formula is AIC $=-2 L L+2 K$ and the BIC formula is BIC $=-2 L L+k(\log N)$ where $\mathrm{LL}=$ model $\log$ likelihood, $\mathrm{K}=$ number of model parameters and $\log \mathrm{N}=$ natural logarithm of sample size. Smaller AIC and BIC values indicate better model performance. See Burnham and Anderson 2002.

13. Instrumental variables included other predictor variables in the composite model, economic evaluations, attitudes towards domestic issues such as the trade-offs between taxing and spending and evaluations of Labour's performance on the issue deemed most important by the respondent.

14. Changes in probabilities of approving the war are calculated with the CLARIFY program (Tomz et al. 2003).

15. Leader image effects also are quite weak if similar calculations are made using the results of the recursive composite model (Table 2, Model A). Although feelings about Labour leader Gordon Brown are statically significant in this model, changes in these feelings can change the probability of approving the war by only 0.06 points.

16. For an analysis of demographic and partisan differences in support for British intervention in Libya, see Clements 2012.

17. The question wordings are: (a) 'There is a strong moral case for Britain participating in military action in Libya'; (b) 'With Britain in economic difficulties, we simply cannot afford to be engaging in military action in Libya'; (c) Britain will benefit in the long run from participating in military action in Libya'; 
(d) 'Involvement in military action in Libya threatens to seriously damage British interests around the world'; (e) 'Using a scale from 0 to 10 where 10 means a complete success, and 0 means a complete failure, how likely is it that Britain's military action in Libya will be successful?'; (f) 'Overall, do you approve or disapprove of Britain's involvement in military action in Libya'. Response categories for items (a)-(d) vary from 'strongly agree' to 'strongly disagree' and response categories for item (f) varies from 'strongly approve' to 'strongly disapprove' Item (e) is a 0 to 10 scale with endpoints as indicated.

18. The risk acceptance-aversion question used is: 'In general do you dislike taking risks, or do you like taking risks? Please use the scale below where 0 means 'really dislike taking risks' and 10 means 'really like taking risks' to indicate how you generally feel about taking risks'.

19. The troop increase of approximately $25 \%$ would be roughly proportional to increases discussed for American forces.

20. A Wilcoxon rank sum test comparing the treatment where respondents are told Cameron supports the action to the control group is significant $(P<0.01)$. All other differences are insignificant.

21. A Wilcoxon rank sum test comparing the treatment where respondents are told Cameron supports the action and Gordon Brown opposes the proposal to the control group is significant $(P<0.01)$. Opposition to the proposal among those in this treatment is $64 \%$. The test comparing the treatment where Brown supports and Cameron opposes to the treatment where Cameron supports and Brown opposes is significant $(P<0.05)$.

22. Clarke et al. 2009b, ch. 3 .

23. See, e.g., Clarke et al. 2009a; 2009b.

24. The Conservatives supported British participation in the Iraq War and the Liberal Democrats were opposed. Labour was deeply divided, with numerous Labour MPs and many party activists decrying Prime Minister Tony Blair's decision to join the US-led 'coalition of the willing' that invaded Iraq in March 2003. These intra-party divisions deepened as war continued. On the co-variance between the foreign policy postures of British citizens and attitudes towards the parties and their leaders, see Reifler et al. 2011.

\section{Bibliography}

Aday, S. (2010) 'Chasing the bad news: An analysis of 2005 Iraq and Afghanistan War coverage on NBC and Fox News channel', Journal of Communication, 60, 144-164.

Aday, S., Cluverius, J. and Livingston, S. (2005) 'As goes the statue so goes the war: The emergence of the victory frame in television coverage of the Iraq War', Journal of Broadcasting $\theta$ Electronic Media, 49, 314-331.

Ajzen, I. and Fishbein, M. (1980) Understanding Attitudes and Predicting Social Behavior (Englewood Cliffs NJ: Prentice-Hall).

Althaus, S. and Coe, K. (2011) 'Priming patriots: Social identity processes and the dynamics of public support for war', Public Opinion Quarterly, 75, 65-88.

Alvarez, R. M. and Glasgow, G. (1999) 'Two-stage estimation of non-recursive choice models', Political Analysis, 8, 147-165.

Ansolabehere, S. and Schaffner, B. F. (2011) 'Re-examining the validity of different survey modes for measuring public opinion in the US: Findings from a 2010 multi-mode comparison'. Paper presented at the AAPOR Annual Conference, Phoenix AZ, 12-15 May.

Baum, M. A. and Groeling, T. (2009) 'Shot by the messenger: Public opinion and partisan cues regarding national security and war', Political Behavior, 31, 157-186.

Berinsky, A. J. (2007) 'Assuming the costs of war: Events, elites, and American public support for military conflict', Journal of Politics, 69, 975-997.

Berinsky, A. J. (2009) In Time of War: Understanding Public Opinion, From World War II to Iraq (Chicago IL: University of Chicago Press).

Berinsky, A. J. and Druckman, J. (2007) 'Public opinion research and support for the Iraq War', Public Opinion Quarterly, 71, 126-141.

Berinsky, A. J. and Kinder, D. R. (2006) 'Making sense of issues through media frames: Understanding the Kosovo crisis', Journal of Politics, 68, 640-656.

Blais, A. (2000) To Vote or Not to Vote: The Merits and Limits of Rational Choice Theory (Pittsburgh PA: University of Pittsburgh Press). 
Boettcher, W. A. and Cobb, M. D. (2006) 'Echoes of Vietnam? Casualty framing and public perceptions of success and failure in Iraq', Journal of Conflict Resolution, 50, 831-854.

Boettcher, W. A. and Cobb, M. D. (2009) 'Don't let them die in vain: Casualty frames and public tolerance for escalating commitment in Iraq', Journal of Conflict Resolution, 55, 677-697.

Burnham, K. P. and Anderson, D. R. (2002) Model Selection and Multimodel Inference: A Practical InformationTheoretic Approach (2nd edn) (New York: Springer-Verlag).

Butler, D. and Stokes, D. E. (1969) Political Change in Britain: Forces Shaping Electoral Choice (New York: St. Martin's Press).

Chapman, T. L. (2009) 'Audience beliefs and international organization legitimacy', International Organization, 63, 733-764.

Clarke, H. D., Sanders, D., Stewart, M. C. and Whiteley, P. F. (eds) (2008) 'Internet surveys and national election studies: A symposium', Journal of Elections, Public Opinion and Parties, 18, 327-330.

Clarke, H. D., Kornberg, A. and Scotto, T. J. (2009a) Making Political Choices: Canada and the United States (Toronto: University of Toronto Press).

Clarke, H. D., Sanders, D., Stewart, M. C. and Whiteley, P. (2009b) Performance Politics and the British Voter (Cambridge: Cambridge University Press).

Clements, B. (2012) 'Public opinion in Britain towards military action in Libya: A micro-level analysis', Politics, 32, 109-119.

Converse, P. E. (1964) 'The nature of belief systems in mass publics', in D. E. Apter (ed.), Ideology and Discontent (Glencoe IL: The Free Press), 206-261.

Delli Carpini, M. and Keeter, S. (1997) What Americans Know about Politics and Why It Matters (New Haven CT: Yale University Press).

Eichenberg, R. C. (2003) 'Gender differences in public attitudes toward the use of force by the United States, 1990-2003', International Security, 28, 110-141.

Elshtain, J. B. (1987) Women and War (New York: Basic Books).

Feaver, P. D. and Gelpi, C. (2004) Choosing Your Battles: American Civil-Military Relations and the Use of Force (Princeton NJ: Princeton University Press).

Gartner, S. S. (2008) 'The multiple effects of casualties on public support for war: An experimental approach', American Political Science Review, 102, 95-106.

Gartner, S. S. and Segura, G. (1998) 'War, casualties, and public opinion', Journal of Conflict Resolution, 42:3, 278-300.

Gelman, A., King, G. and Boscardin, J. (1998) 'Estimating the probability of events that have never occurred: When is your vote decisive?', Journal of the American Statistical Association, 93, 1-9.

Gelpi, C. (2010) 'Performing on cue? The formation of public attitudes toward war', Journal of Conflict Resolution, 54, 88-116.

Gelpi, C., Feaver, P. and Reifler, J. (2005/2006) 'Success matters: Casualty sensitivity and the war in Iraq', International Security, 30, 7-46.

Gelpi, C., Reifler, J. and Feaver, P. (2007) 'Iraq and the vote: Retrospective and prospective foreign policy judgments on candidate choice and casualty tolerance', Political Behavior, 29, 151-174.

Gelpi, C., Feaver, P. D. and Reifler, J. (2009) Paying the Human Costs of War (Princeton NJ: Princeton University Press).

Gigerenzer, G. (2008) Rationality for Mortals (Cambridge: Cambridge University Press).

Gigerenzer, G., Hertwig, R. and Pachur, T. (eds) (2011) Heuristics: The Foundations of Adaptive Behavior (Oxford: Oxford University Press).

Goldstein, J. (2003) War and Gender: How Gender Shapes the War System and Vice Versa (New York: Cambridge University Press).

Grieco, J. M., Gelpi, C., Reifler, J. and Feaver, P. D. (2011) 'Let's get a second opinion: International institutions and American public support for war', International Studies Quarterly, 55, 563-583.

Herrmann, R. K., Tetlock, P. E. and Visser, P. S. (1999) 'Mass public decisions to go to war: A cognitiveinteractionist approach', American Political Science Review, 93, 553-573.

Holsti, O. R. (1996/2004 (revised)) Public Opinion and American Foreign Policy (Ann Arbor MI: University of Michigan Press).

Inglehart, R. (1989) Culture Shift in Advanced Industrial Democracy (Princeton NJ: Princeton University Press). 
Jenkins-Smith, H. C. and Herron, K. G. (2009) 'Rock and a hard place: Public willingness to trade civil rights and liberties for greater security', Politics e Policy, 37, 1095-1129.

Jentleson, B. W. (1992) 'The pretty prudent public: Post-Vietnam American opinion on the use of military force', International Studies Quarterly, 36, 49-73.

Jentleson, B. W. and Britton, R. L. (1998) 'Still pretty prudent: Post-cold war American public opinion on the use of military force', Journal of Conflict Resolution, 42, 395-417.

Johns, R. (2009) 'Tracing foreign policy decisions: A study of citizens' use of heuristics', The British Journal of Politics $\theta$ International Relations, 11, 574-592.

Johnson, D. and Tierney, D. (2006) Failing to Win: Perceptions of Victory and Defeat in International Politics (Cambridge MA: Harvard University Press).

Kahneman, D. (2011) Thinking Fast and Slow (New York: Farrar, Stauss and Giroux).

Kahneman, D., Slovic, P. and Tversky, A. (1982) Judgment Under Uncertainty: Heuristics and Biases (New York: Cambridge University Press).

Karol, D. and Miguel, E. (2007) 'The electoral cost of war: Iraq casualties and the 2004 presidential election', Journal of Politics, 69, 633-644.

Kriner, D. L. and Shen, F. X. (2007) 'Iraq casualties and the 2006 senate elections', Legislative Studies Quarterly, 32, 507-530.

Kriner, D. L. and Wilson, G. (2010) 'Elites, events, and British support for the war in Afghanistan.' Paper presented at the Annual Meeting of the American Political Science Association, Washington DC, 2-5 September.

Kuklinski, J. H. and Quirk, P. J. (2000) 'Reconsidering the rational public: Cognition, heuristics and mass opinion', in A. Lupia, M. McCubbins and S. Popkin (eds), Elements of Political Reason (Cambridge: Cambridge University Press), 153-182.

Kull, S. and Destler, I. M. (1999) Misreading the Public: The Myth of A New Isolationism (Washington DC: The Brookings Institution).

Larson, E. V. (1996) Casualties and Consensus: The Historical Role of Casualties in Domestic Support for US Military Operations (Santa Monica CA: RAND Corporation).

Liberman, P. (2006) 'An eye for an eye: Public support for war against evildoers', International Organization, $60,687-722$.

Liberman, P. (2007) 'Punitiveness and US elite support for the 1991 Persian Gulf War', Journal of Conflict Resolution, 51, 3-32.

Lodge, M. and Taber, C. (2000) 'Three steps towards a theory of motivated political reasoning', in A. Lupia, M. McCubbins and S. Popkin (eds), Elements of Political Reason (Cambridge: Cambridge University Press), 183-213.

Long, J. S. and Freese, J. (2006) Regression Models for Categorical Dependent Variables Using Stata (2nd edn) (College Station TX: Stata Press).

Mosley, A. (2009) 'Just war theory', in J. Fieser and B. Dowden (eds), The Internet Encyclopedia of Philosophy. Available online at: http://www.iep.utm.edu/justwar/. 10 February 2009. [accessed 4 January 2013].

Mueller, J. (1973) War, Presidents and Public Opinion (New York: Wiley).

Nicholson, S. P. (2010) 'Events, elites, and war opinion.' Paper presented at the Annual Meeting of the American Political Science Association, Washington, DC, 2-5 September.

Page, B. and Shapiro, R. Y. (1992) The Rational Public: Fifty Years of Trends in American's Policy Preferences (Chicago IL: University of Chicago Press).

Redlawsk, D. P. (2002) 'Hot cognition or cool consideration? Testing the effects of motivated reasoning on political decision making', Journal of Politics, 64, 1021-1044.

Reifler, J., Scotto, T. J. and Clarke, H. D. (2011) 'Foreign policy beliefs in contemporary Britain: Structure and relevance', International Studies Quarterly, 55, 245-266.

Ricks, T. E. (2009) The Gamble: General Petraeus and the Untold Story of the American Surge in Iraq 2006-2008 (New York: Penguin).

Riker, W. and Ordeshook, P. (1968) 'A theory of the calculus of voting', American Political Science Review, $62,25-42$.

Sanders, D., Clarke, H. D., Stewart, M. C. and Whiteley, P. (2007) 'Does mode matter for modeling political choice?: Evidence from the 2005 British election study', Political Analysis, 15, 257-285. 
Sky, E. (2011) 'Iraq, from surge to sovereignty: Winding down the war in Iraq', Foreign Affairs, 90 , $117-127$.

Sniderman, P. M., Brody, R. A. and Tetlock, P. E. (1993) Reasoning and Choice: Explorations in Political Psychology (Cambridge: Cambridge University Press).

Stein, R. (2011) War as punishment: Retributive justice and the public support for the use of force'. Paper presented at the 2011 Annual Meeting of the Midwest Political Science Association, Chicago IL, 31 March-3 April .

Tomz, M., Wittenberg, J. and King, G. (2003) CLARIFY: Software for Interpreting and Presenting Statistical Results (Cambridge, MA: Harvard University, Department of Government).

Vickers, R. (2011) The Labour Party and the World: Volume 2: Labour's Foreign Policy Since 1951 (Manchester: University of Manchester Press). 